\title{
PELAYANAN KESEHATAN TRADISIONAL DAN PERLINDUNGAN HUKUM BAGI PASIEN
}

\author{
Dian Kartika, Pan Lindawaty S. Sewu dan Rullyanto W. \\ diankartika@gmail.com \\ Magister Hukum Kesehatan \\ Universitas Katolik Soegijapranata Semarang
}

\begin{abstract}
ABSTRAK
Pelayanan kesehatan tradisional merupakan terapi alternatif pengganti untuk memecahkan masalah kesehatan masyarakat. Perkembangan pelayanan kesehatan tradisional, disertai dengan antusiasme orang dalam pengobatan tradisional, menegaskan bahwa pemerintah memiliki tugas untuk meningkatkan dan mengontrol pelayanan pengobatan tradisional sebagai perwujudan perlindungan untuk masyarakat. melalui undang-undang No.36 Tahun 2009 Tentang Kesehatan. Kemudian didukung dengan peraturan Kepmenkes RI No 10761Menkes/SKIVII1/2003 tentang Penyelengaraan Pengobatan Tradisional dimana pemerintah membentuk Sentra Pengembangan Dan Penerapan Pengobatan Tradisional (SP3T) yang diwajibkan untuk melakukan pemeriksaan pada setiap pelayanan pengobatan tradisional.

Oleh karena itu telah dilakukan penelitian deskriptif analitis, yaitu dengan membuat deskripsi atau gambaran secara sistematis, aktual dan akurat mengenai fakta, sifat dan hubungan antar fenomena yang diteliti sambil menganalisisnya, yaitu mencari sebab-akibat dari suatu hal dan menguraikannya secara konsisten dan sistematis serta logis. Metode pendekatan yang digunakan dalam penelitian tesis ini, yaitu yuridis normatif yaitu suatu cara dalam penelitian hukum yang dilakukan terhadap bahan pustaka atau data sekunder dengan menggunakan metode berpikir deduktif berdasarkan kriterium kebenaran koheren.

Hasil penelitian menunjukkan, dengan melihat kedua aspek dari unsur-unsur pelayanan kesehatan tradisional dan perlindungan hukum pasien, melalui Pasal 59, 60, 61 Undang-undang Nomor 36 tahun 2009 Tentang Kesehatan dan Kepmenkes Nomor 1076 Tahun 2003 Tentang Penyelenggaraan Pengobatan Tradisional dapat dirumuskan jawaban sementara yakni: jika terpenuhinya syarat dan standar suatu pelayanan kesehatan tradisional maka dipenuhinya perlindungan hukum bagi pasien.
\end{abstract}

Kata kunci: pengobatan tradisional, pelayanan kesehatan, perlindungan hukum 


\section{PENDAHULUAN}

Kesehatan merupakan Hak Asasi Manusia dan salah satu unsur kesejahteraan yang harus diwujudkan sesuai dengan cita-cita bangsa Indonesia sebagaimana dimaksud dalam Pancasila dan Undang-Undang Dasar Negara Republik Indonesia tahun 1945. Sesuai konsep negara kesejahteraan (welfare state) setiap warga Negara berhak atas kesehatan fisik dan mental termasuk fasilitas dan pelayanan yang diselenggarakan oleh Negara dan instansi yang ditunjuk oleh Negara, termasuk masyarakat miskin yang notabene merupakan warga mayoritas penduduk Indonesia. Oleh karena itu, usaha-usaha manusia untuk upaya perlindungan diri dan penyembuhan penyakit selalu menjadi prioritas untuk diupayakan.

Pada awalnya penyakit dianggap sebagai suatu kutukan dari Tuhan dihubungkan dengan perilaku masa lalu yang dianggap jahat sehingga dalam upaya penyembuhannya dilakukan dengan ritual-ritual, sehingga ilmu kedoktertan berkembang lambat. Dampaknya kondisi kekurangan nutrisi dan minimnya upaya pengobatan, sering mengakibatkan kematian. Kemudian manusia berusaha mencari segala cara mulai dari mengunakan kekuatan supranatrural hingga mencoba segala jenis makanan yang dianggap dapat memberikan kekuatan untuk bertahan hidup. Seiring dengan berkembangnya peradaban manusia, ilmu kedokteran pun mengalami perkembangan sesuai dengan zamannya. Hal ini ditandai dengan munculnya Fakultas Kedokteran di berbagai belahan dunia. Perkembangan ilmu kedokteran di daratan Eropa menggunakan metode penelitian dengan pembuktian secara ilmiah yang kemudian dikenal sebagai pengobatan formal atau modern. Sementara itu, daratan Cina dan beberapa negara asia lainnya juga mengembangkan ilmu kedokteran berdasarkan kemampuan yang bersifat turun temurun dengan menggunakan bahan-bahan herbal yang kemudian dikenal sebagai upaya pengobatan tradisional. Kedua metode pengobatan ini berkembang dan menyebar ke berbagai daerah termasuk Indonesia. Indonesia menerima kedua bentuk metode perkembangan ilmu pengobatan, baik yang tradisional maupun yang bersifat formal modern.

Dalam perkembangan dunia kesehatan selama ini, telah terjadi perubahan orientasi, baik tata nilai maupun pemikiran mengenai upaya pemecahan masalah kesehatan yang dipengaruhi oleh politik, ekonomi, sosial budaya, ilmu pengetahuan dan teknologi. Pada saat ini pada era dominasi ekonomi, dimana biaya kesehatan menjadi semakin mahal menyebabkan beban pembiayaan yang sangat berat yang harus ditanggung masyarakat. Bagi anggota masyarakat yang berkemampuan secara ekonomi, memiliki keleluasan dalam memilih pelayanan kesehatan melalui rumah sakit atau dokter, tetapi juga pada rumah sakit dan dokter-dokter di luar negeri yang berkaitan dan bersifat privacy, sementara itu bagi masyarakat yang kurang atau bahkan tidak berkemampuan memilih pelayanan kesehatan modern, mereka akan lebih memilih pelayanan untuk kesehatan mereka secara alternatif atau tradisional. Gejala-gejala seperti ini seolah-olah menjadi suatu legitimasi kolektif, bahwa pola pengobatan modern hanya dimiliki oleh orang yang kaya, sedangkan pengobatan tadisional dan alternatif dimiliki oleh kelompok kalangan bawah (miskin).

Saat ini muncul gejala berbagai jenis usaha yang juga menawarkan pelayanan kesehatan dengan metode pengobatan alternatif ataupun menggunakan obat/ramuan tradisional makin banyak bermunculan. Penawaran-penawaran pelayanan yang menawarkan harga yang relatif terjangkau oleh masyarakat tentunya menarik perhatian masyarakat. Metode pengobatan dengan menggunakan bahan-bahan herbal dan menggunakan jasa tindakan terapis menjadi peralihan dan pilihan masyarakat dalam upaya mencari bentuk pengobatan bagi masalah kesehatan yang diderita, dan menjadi cara menyingkapi masalah harga pengobatan modern yang cenderung mahal.

Terdapat paradigma di masyarakat bahwa pelayanan kesehatan alternatif dapat mengobati penyakit kronis, yang belum dapat dijawab dengan menggunakan teori pengobatan modern. Ketakutan terhadap tindakan operasi serta obat-obatan akan memberi dampak negatif 
bagi organ tubuh menjadi pertimbangan masyarakat untuk lebih memilih pelayanan kesehatan tradisional.

Pada tahun 2009 WHO ( World Health Organization) mencatat sekitar 30-50\% penduduk China masih menggunakan sistem pengobatan tradisional /CAM (Complement Alternative Medicine) untuk mendukung kesehatan mereka; di Ghana, Mali, Nigeria and Zambia 60\% ; Di Eropa, Amerika utara dan daerah sekitarnya 50\% dari seluruh populasi; di San Francisco, London sekitar $75 \%$. Fakta tersebut menunjukkan bahwa pengobatan tradisional memiliki arti penting yaitu mendukung kehidupan dan mempunyai potensi yang progresif untuk dikembangkan.

Menurut Profil Kesehatan Indonesia Tahun 2008, angka kesakitan penduduk secara nasional sebesar $33,24 \%$, dari jumlah tersebut sebesar $65,59 \%$ memilih berobat sendiri dengan menggunakan obat-obatan modern dan tradisional (termasuk berobat di klinik tradisional), sisanya sebesar $34,41 \%$ memilih berobat jalan ke puskesmas, praktek dokter dan fasilitas kesehatan lainnya. Hal ini menunjukkan masyarakat terhadap pengobatan tradisional cukup tinggi .

Pilihan itu didasarkan selain karena mahalnya pengobatan modern dan beberapa faktor lainnya, adanya isu ingin kembali ke alam (back to nature) memicu penggunaan pelayanan kesehatan tradisional.

Menjadi tanggung jawab pemerintah untuk menaikkan derajat kesehatan masyarakat secara optimal selain menggunakan pelayanan kesehatan formal/ modern juga menggunakan pengobatan tradisional. Pengobatan tradisional yang telah terbukti manfaat dan keamanannya diharapkan secara bersama-sama dapat memberikan layanan kesehatan kepada masyarakat. Hal ini diatur dalam Pasal 59 Undang-Undang Nomor 36 Tahun 2009 Tentang Kesehatan yang menjadi landasan pengawasan di bidang pengobatan tradisional guna menjadi mutu dan keamanan penggunaan obat tradisional. Undang-undang ini menyatakan bahwa penyelenggaraan upaya kesehatan sebagaimana dimaksud dilaksanakan melalui "pengobatan tradisional". Pengobatan tradisional yang telah dan dapat dipertanggungjawabkan manfaat dan keamanannya perlu terus ditingkatkan serta dikembangkan untuk mewujudkan derajat kesehatan masyarakat yang optimal.

Ketentuan mengenai pengobatan tradisional juga ditetapkan dengan Keputusan Menteri Kesehatan Nomor 1076 Tahun 2003 Tentang Penyelenggaraan Pengobatan Tradisional. Hal ini bertujuan membina upaya pengobatan tradisional, memberikan perlindungan kepada masyarakat dan menginvestarisasi jumlah pengobatan tradisional, jenis dan cara pengobatannya. Semua pengobatan tradisional yang menjalankan pekerjaan pengobatan tradisional wajib mendaftarkan diri kepada Kepala Dinas Kesehatan Kabupaten/Kota setempat untuk memperoleh Surat Terdaftar Pengobat Tradisional (STPT). Meskipun pemerintah sudah mulai memperhatikan pengobatan maupun obat tradisional, serta meningkatnya jumlah masyarakat pengguna jenis pelayanan kesehatan ini, namun baru sedikit penelitian-penelitian yang mengkaji lebih dalam mengenai pelayanan kesehatan tradisional ini.

Pada praktiknya, banyak masyarakat yang termotivasi dan memiliki kepercayaan untuk berobat pada pelayanan kesehatan tradisional, karena dianggap dapat mengobati penyakit kronis serta ketidakpercayaan masyarakat terhadap pengobatan modern karena dianggap gagal dalam mengobati penyakitnya. Hal lain yang menjadi penyebab masyarakat menggunakan pelayanan kesehatan tradisional adalah ketakutan tindakan operasi dan ketidakpuasan terhadap pengobatan modern, adanya paradigma bahwa mengkonsumsi obat-obatan akan memberi dampak negatif bagi organ tubuh juga memberi motivasi masyarakat memilih pelayanan kesehatan tradisional. Selain pelayanan pengobatan tradisional lebih menguntungkan dari pengobatan modern, pengobatan tradisional jauh lebih cepat tuntas, murah dan alami. Disamping masih menjadi keraguan masyarakat bahwa pelayanan pengobatan tradisional menurut masyarakat, terhadap tindakan pengobatan yang dilakukan melalui pelayanan 
kesehatan tradisional belum semua yang berada dalam pengawasan pemerintah, obatnya tidak praktis, tidak enak, kebersihannya tidak terjamin sehingga perlindungan terhadap pasiennya masih dipertanyakan ${ }^{1}$.

\section{Unsur-unsur mengenai Pelayanan Kesehatan Tradisional}

Pelayanan kesehatan tradisional merupakan suatu pelayanan dimana pengobatan dan/atau perawatan yang diberikan dengan cara dan obat yang mengacu pada pengalaman dan keterampilan turun temurun secara empiris yang dapat dipertanggungjawabkan dan diterapkan sesuai dengan norma yang berlaku di masyarakat.

Berdasarkan ketentuan tersebut dapat dijabarkan bahwa pengertian pelayanan kesehatan tradisional mengandung persyaratan :

1. Adanya aktifitas pengobatan dan atau perawatan.

2. Menggunakan cara atau obat

3. Berdasarkan pengalaman dan ketrampilan yang turun-temurun

4. Dapat dipertanggung jawabkan secara empiris

5. Penerapannya sesuai dengan norma yang berlaku dimasyarakat.

Oleh karena itu dapat disimpulkan bahwa tidak semua jenis pengobatan / perawatan yang dilakukan Berdasarkan pengalaman dan ketrampilan masuk dalam katagori yang dimaksudkan oleh Undang-Undang , melainkan harus memenuhi uji empirik dan tidak melanggar norma yang berlaku di masyarakat.

Saat ini keberadaan pengobatan tradisional (Battra) di Indonesia cukup diakui dan banyak dimanfaatkan oleh masyarakat untuk memenuhi kebutuhan akan kesehatan. Pemanfaatan pengobatan tradisional pada umumnya lebih diutamakan sebagai upaya pengobatan suatu penyakit. Dalam pelayanan kesehatan, Battra merupakan salah satu pilihan bagi masyarakat dalam mencari pemecahan masalah kesehatan. Masyarakat memilih cara pengobatan tradisional pada umumnya karena obat tradisional mudah diperoleh dan biayanya relatif murah dibandingkan pengobatan modern.

Untuk dapat dimanfaatkannya secara luas oleh masyarakat, pengobatan tradisional dalam pelayanan kesehatan, banyak yang harus diperhatikan. Diantaranya, pelayanan kesehatan harus $^{2}$ :

1) Bersifat jelas. Artinya dapat diukur dengan baik, termasuk ukuran terhadap penyimpanganpenyimpangan yang mungkin terjadi. Penyimpangan yang terjadi bisa berasal dari pelaksana pengobatan tradisional tersebut ataupun pemerintah seperti kurangnya pengawasan dari pemerintah.

2) Masuk akal. Suatu standar yang tidak masuk akal, bukan saja akan sulit dimanfaatkan tetapi juga akan menimbulkan frustasi bagi para professional atau praktisi pengobatan. Setiap metode atau cara yang digunakan dalam pengobatan harus dapat dipertanggungjawabkan.

3) Mudah dimengerti. Suatu standar yang tidak mudah dimengerti juga akan menyulitkan tenaga pelaksana sehingga sulit terpenuhi untuk suatu pelayanan kesehatan.

4) Dapat dipercaya. Tidak ada gunanya menentukan standar yang sulit karena tidak akan mampu tercapai dalam pemenuhan pelayanan kesehatan. Karena itu sering disebutkan, dalam menentukan standar, salah satu syarat yang harus dipenuhi ialah harus sesuai dengan kondisi organisasi yang dimiliki. Dapat dipercaya kebenarannya agar bermanfaat untuk masyarakat.

1 Jusuf Hanafiah, Amri Amir, 2007. Etika Kedokteran dan Hukum Kesehatan, Edisi 4, Jakarta: EGC, hlm.142

2 Clinical Practice Guideline, 1990 
5) Absah. Artinya ada hubungan yang kuat dan dapat didemintrasikan antara standar dengan mutu pelayanan yang diwakilinya.

6) Meyakinkan. Artinya mewakili persyaratan yang ditetapkan. Apabila tingkat keyakinan suatu pelayanan terlalu rendah akan menyebabkan persyaratan lainnya menjadi tidak berarti dan tidak bisa dterima dimasyarakat.

7) Mantap, Spesifik dan Eksplisit. Artinya tidak terpengaruh oleh perubahan oleh waktu, bersifat khas dan gamblang. Dengan persyaratan ini diharapkan, bukan saja mutu pengobatan tradisional akan dapat ditingkatkan, tapi yang penting lagi munculnya berbagai efek samping yang secara medis tidak dapat dipertanggung jawabkan, akan dapat dihindari. Akan tetapi, yang terjadi saat ini banyaknya bermunculan konsep pengobatan tradisional dengan supranatural. Dimana konsep ini standarnya satu sama lain terlihat berbeda dengan standar pengobatan seharusnya dan diragukan kejelasan, kepercayaannya, keabsahan, keyakinannya sehingga menyebabkan standarisasi suatu pelayanan yang baik akan sulit dilakukan. Untuk itu mengharuskan pemerintah untuk lebih mencermati dan melakukan pengawasan terhadap para praktisi pelayanan kesehatan sebagai wujud perlindungan pemerintah kepada warga negaranya.

Tanggungjawab pemerintah ini diatur dalam Pasal 14-20 Undang-undang No.36 Tahun 2009 Tentang Kesehatan.

Tanggungjawab pemerintah terhadap pelayanan kesehatan tradisional sendiri diperjelas pada Pasal 59 Undang-undang No.36 Tahun 2009 Tentang Kesehatan bahwa berdasarkan cara pengobatannya, pelayanan kesehatan tradisional terbagi menjadi pelayanan kesehatan tradisional yang menggunakan keterampilan; dan pelayanan kesehatan tradisional yang menggunakan ramuan. Pelayanan kesehatan tradisional ini dibina dan diawasi oleh Pemerintah agar dapat dipertanggungjawabkan manfaat dan keamanannya serta tidak bertentangan dengan norma agama. Ketentuan lebih lanjut mengenai tata cara dan jenis pelayanan kesehatan tradisional baik itu yang menggunakan keterampilan maupun ramuan diatur dengan Peraturan Pemerintah.

Pasal 60 Undang-undang No.36 Tahun 2009 Tentang Kesehatan memuat bahwa setiap orang yang melakukan pelayanan kesehatan tradisional yang menggunakan alat dan teknologi harus mendapat izin dari lembaga kesehatan yang berwenang. Penggunaan alat dan teknologi tersebut harus dapat dipertanggungjawabkan manfaat dan keamanannya serta tidak bertentangan dengan norma agama dan kebudayaan masyarakat.

Sedangkan pada Pasal 61 Undang-undang No.36 Tahun 2009 Tentang Kesehatan disebutkan bahwa Masyarakat diberi kesempatan yang seluas-luasnya untuk mengembangkan, meningkatkan dan menggunakan pelayanan kesehatan tradisional yang dapat dipertanggungjawabkan manfaat dan keamanannya. Pemerintah wajib mengatur dan mengawasi pelayanan kesehatan tradisional tersebut dengan didasarkan pada keamanan, kepentingan, dan perlindungan masyarakat.

Selain peraturan perundangan diatas, pelayanan kesehatan tradisional juga diatur dalam Keputusan Menteri Kesehatan No. 1076 Tahun 2003 Tentang Penyelenggaraan Pengobatan Tradisonal, yang mana bagi setiap pihak yang akan melakukan pekerjaan pelayanan pengobatan tradisional wajib mendaftarkan diri ke Kepala Dinas Kesehatan Kabupaten /kota setempat untuk memperoleh Surat Terdaftar Pengobat Tradisional (STPT) agar pelayanan kesehatan tradisional berada dalam pengawasan pemerintah.

Oleh karena itu pelayanan kesehatan tradisional tidak dapat berdiri sendiri. Melainkan didukung oleh ketentuan-ketentuan yang mengatur pelaksanaan dari pelayanan kesehatan tradisional itu sendiri. Agar dapat tercapai suatu perlindungan hukum bagi pasien. 


\section{Unsur-unsur Perlindungan Hukum Pasien}

Perlindungan hukum dapat diartikan sebagai jaminan yang diberikan oleh pemerintah kepada semua pihak untuk melaksanakan hak dan segala kepentingan hukum yang dimiliki sehingga setiap warga dapat melaksanakan hak dan kewajiban secara aman dan tertib ${ }^{3}$.

Perlindungan hukum merupakan hak asasi manusia, setiap warga Negara berhak memperoleh perlindungan hukum yang sama. Hal tersebut ditegaskan dalam Pasal $28 \mathrm{D}$ ayat 1 BAB X A tentang Hak Asasi Manusia Undang-Undang Dasar 1945 amandemen ke-4 bahwa Negara berkewajiban untuk memberikan pengakuan jaminan, perlindungan dan kepastian hukum, serta keadilan yang mengarah kepada perlindungan hukum terhadap negaranya yang meliputi perlindungan kesehatan, perlindungan sosial, perlindungan politik, perlindungan budaya, dan perlindungan lainnya.

Perlindungan hukum merupakan tanggung jawab negara yang harus direalisasikan untuk memberikan pelayanan dan keadilan hukum bagi warganya demi terciptanya ketertiban dan keselarasan dalam kehidupan. Bagaimanapun perlindungan hukum merupakan hak bagi setiap warga negara dimanapun berada dan pemerintah sebagai bagian dari negara mempunyai tanggung jawab besar untuk menegakkan hukum demi terselenggaranya perlindungan hukum bagi warganya tanpa ada diskriminasi. Campur tangan yang dilakukan negara bertujuan untuk meningkatkan kesejahteraan bagi warga negara dapat diwujudkan melalui sarana hukum dengan berbagai bentuk kebijakan serta penetapan peraturan perundang-undangan khusunya dalam bidang ekonomi.

Uraian mengenai konsep perlindungan hukum diatas dapat digambarkan secara sederhana dalam bagan berikut:

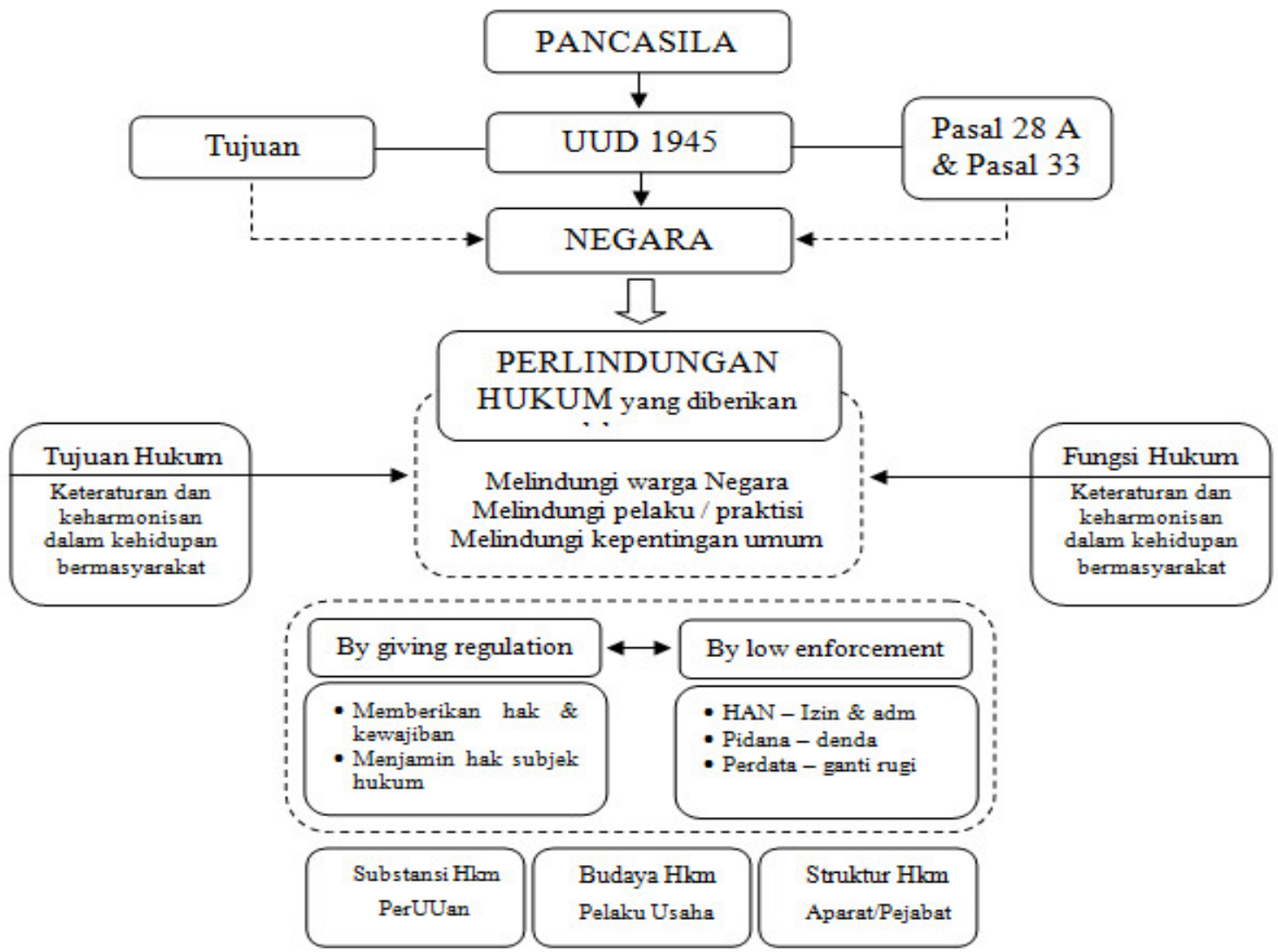

3 Koermiatmanto Soetoprawiro, Peraturan Perindungan Hak-Hak Perempuan dan Anak-Anak dalam Hukum Kewarganegaraan Indonesia, Journal Hukum Pro Justisia XX nomor 3 Juli,Bandung, 2002, hlm.20. 
Salah satu tindakan yang dapat memajukan dan mengembangkan pembangunan adalah melalui perlindungan hukum dalam bidang kesehatan melalui pelayanan kesehatan. Peran pemerintah dalam melakukan pembangunan tersebut sangat penting. Pemerintah diharapkan membuat suatu aturan yang memihak pada masyarakat. Peraturan-peraturan yang dibuat harus dapat menciptakan suatu perlindungan hukum yang tepat bagi masyarakat khusunya para praktisi pemberi pelayanan kesehatan sesuai dengan tujuan dan fungsi hukum yang berlandaskan semangat Pancasila dan Undang-Undang Dasar 1945.

Sedangkan uraian mengenai hubungan praktisi dan pasien sebagai konsumen pelayanan kesehatan dapat dilihat dari bagan sederhana dibawah:

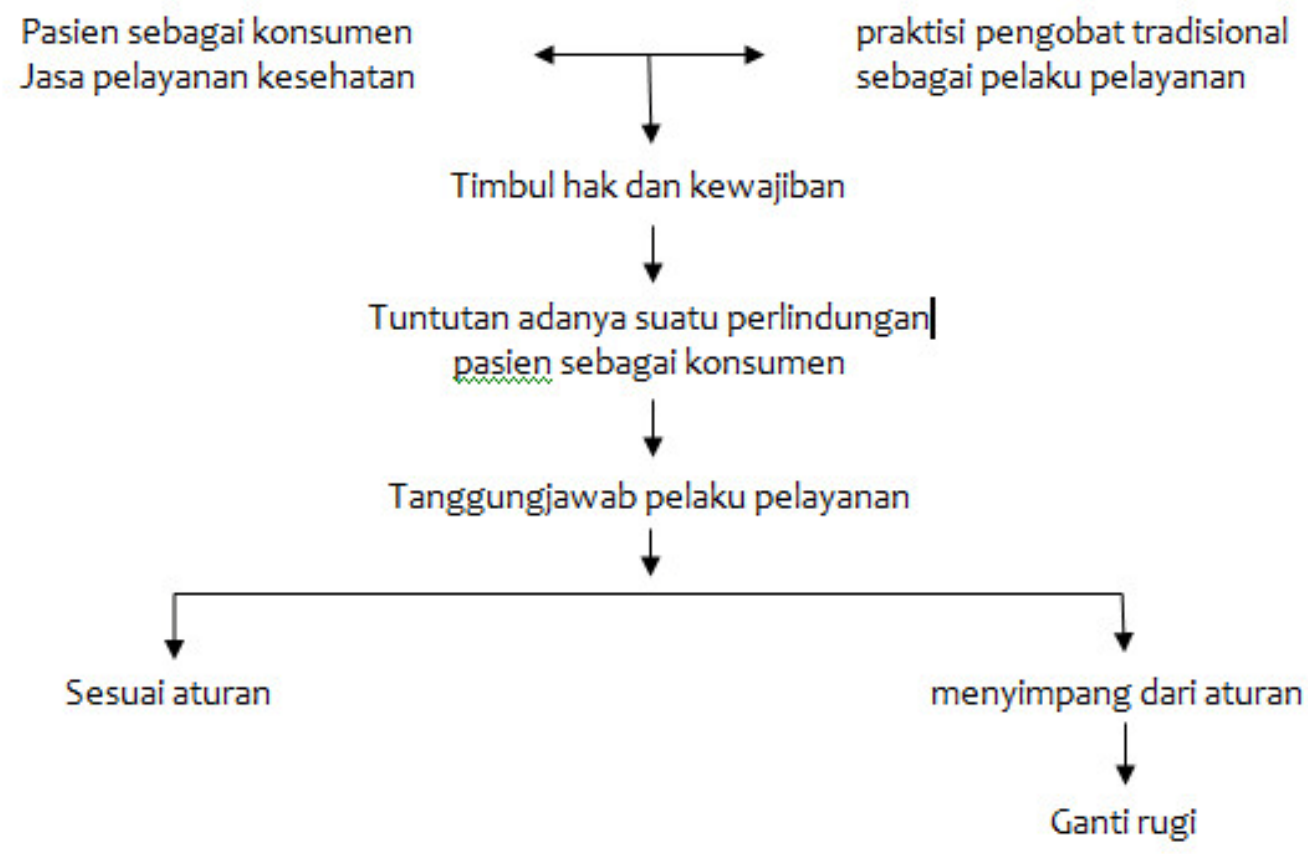

\section{Unsur-unsur mengenai Pelayanan Kesehatan Tradisional dan Perlindungan Hukum bagi Pasien}

Suatu pusat Pelayanan Kesehatan Tradisional merupakan sarana pelayanan kesehatan yang menyediakan dan menyelenggarakan upaya pelayanan kesehatan dimana pengobatan dan/atau perawatan yang diberikan dengan cara dan obat yang mengacu pada pengalaman dan keterampilan turun temurun dengan melibatkan praktisi kesehatan dibidangnya.

Dalam pelayanan di bidang kesehatan, tidak terpisah akan adanya seorang tenaga kesehatan dengan konsumen, dalam hal ini pasien. Pasien memiliki dua macam hak dasar yaitu hak dasar sosial berupa pelayanan kesehatan (health care) dan hak dasar individu yakni yang menyangkut hak dalam hal menentukan nasib sendiri (Right of Self determination) berkaitan dengan hak untuk mendapatkan informasi mengenai kondisi kesehatannya,hak untuk memberikan persetujuan atau penolakan tindakan medik, dan hak untuk mendapatkan pendapat kedua (second opinion). Pasien dikenal sebagai penerima jasa pelayanan kesehatan dari pemberi jasa pelayanan kesehatan dalam bidang perawatan kesehatan. Dalam hubungannya dengan tenaga kesehatan, tenaga kesehatan mempunyai posisi yang dominan apabila dibandingkan dengan kedudukan pasien yang awam dalam bidang kesehatan. Pasien dalam hal ini, dituntut untuk mengikuti nasehat dari tenaga kesehatan, yang mana lebih mengetahui akan bidang pengetahuan tersebut. Dengan demikian pasien senantiasa harus percaya pada kemampuan tenaga kesehatan tempat dia menyerahkan nasibnya. Pasien sebagai konsumen dalam hal ini, merasa dirinya bergantung dan aman apabila tenaga kesehatan berusaha untuk menyembuhkan 
penyakitnya. Situasi tersebut berakar pada dasar-dasar historis dan kepercayaan yang sudah melembaga dan membudaya di dalam masyarakat. Hingga kini pun kedudukan dan peranan dokter relatif lebih tinggi dan terhormat. Pasien sebagai konsumen jasa di bidang pelayanan medis, dengan melihat perkembangan ilmu dan teknologi kesehatan yang pesat, resiko yang dihadapi semakin tinggi. Oleh karena itu, dalam hubungan antara tenaga kesehatan dengan pasien, misalnya terdapat kesederajatan. Maka dari itu, pasien juga memerlukan perlindungan hukum yang proporsional yang diatur dalam perundang-undangan. Perlindungan tersebut terutama diarahkan kepada kemungkinan-kemungkinan bahwa tenaga kesehatan melakukan kekeliruan karena kelalaian.

Melihat kenyataan tentang pengobatan tradisional yang berkembang pesat di Indonesia, pemerintah mengalami stagnasi dalam melakukan langkah pembinaan. Untuk itu pemerintah mengatur Pelayanan kesehatan tradisional dalam beberapa peraturan perundangan agar tercapainya suatu perlindungan hukum bagi pasien.

Tanggungjawab pemerintah terhadap pelayanan kesehatan tradisional diperjelas pada Pasal 59 Undang-undang No.36 Tahun 2009 Tentang Kesehatan bahwa berdasarkan cara pengobatannya, pelayanan kesehatan tradisional terbagi menjadi pelayanan kesehatan tradisional yang menggunakan keterampilan; dan pelayanan kesehatan tradisional yang menggunakan ramuan. Pelayanan kesehatan tradisional ini dibina dan diawasi oleh Pemerintah agar dapat dipertanggungjawabkan manfaat dan keamanannya serta tidak bertentangan dengan norma agama. Dan ketentuan lebih lanjut mengenai tata cara dan jenis pelayanan kesehatan tradisional baik itu yang menggunakan keterampilan maupun ramuan diatur dengan Peraturan Pemerintah. Disini penulis berpendapat, pasal ini didasarkan oleh asas manfaat dan asas perlindungan yang kemudian disesuaikan dengan kaidah yang berlaku dimasyarakat. Terdapat 4 aspek yang terlibat didalam suatu pusat pelayanan kesehatan tradisional, yaitu tenaga kesehatan, sarana prasarana (mencakup obat dan alat yang digunakan untuk menunjang suatu pelayanan tradisional), metode serta pengguna layanan kesehatan tradisional yang disini disebut pasien. Pasien diartikan sebagai seseorang yang melakukan konsultasi mengenai masalah kesehatannya. Dengan tujuan tercapai suatu ketertiban didalam pelaksanaan dari pelayanan kesehatan tradisional ini. Sehingga perlindungan hukum terhadap pasien pun tercapai. Dengan adanya pasal ini jelas perlindungan hukum terhadap pasien dijamin oleh pemerintah.

Pada Pasal 60 Undang-undang No.36 Tahun 2009 Tentang Kesehatan memuat bahwa setiap orang yang melakukan pelayanan kesehatan tradisional yang menggunakan alat dan teknologi harus mendapat izin dari lembaga kesehatan yang berwenang. Dan penggunaan alat dan teknologi tersebut harus dapat dipertanggungjawabkan manfaat dan keamanannya serta tidak bertentangan dengan norma agama dan kebudayaan masyarakat. Penulis berpendapat, pasal ini didasarkan oleh asas manfaat dan asas perlindungan yang kemudian disesuaikan dengan kaidah agama dan budaya yang berlaku dimasyarakat. Dilihat dari segi penggunaan alat dan teknologi, pelayanan kesehatan tradisional dapat disebut suatu tempat usaha pelayanan kesehatan. Pasien sebagai pengguna pelayanan kesehatannya berperan sebagai konsumen. Konsumen adalah setiap orang pemakai barang dan/ atau jasa yang tersedia dalam masyarakat, baik bagi kepentingan diri sendiri, keluarga, orang lain, maupun makhluk hidup lain dan tidak untuk diperdagangkan. Setiap pusat pelayanan kesehatan tradisional yang menggunakan alat dan tekhnologi perlu memiliki izin dari lembaga berwenang untuk melakukan pelayanan kesehatannya agar aspek perlindungan terhadap pasiennya dapat tercapai. Hal ini menunjukkan bahwa aspek perlindungan hukum terhadap pasien dijamin oleh pemerintah.

Sedangkan pada Pasal 61 Undang-undang No.36 Tahun 2009 Tentang Kesehatan disebutkan bahwa masyarakat diberi kesempatan yang seluas-luasnya untuk mengembangkan, meningkatkan dan menggunakan pelayanan kesehatan tradisional yang dapat dipertanggungjawabkan manfaat dan keamanannya. Pemerintah wajib mengatur dan mengawasi pelayanan kesehatan tradisional tersebut dengan didasarkan pada keamanan, kepentingan, dan 
perlindungan masyarakat. Penulis berpendapat, pasal ini didasarkan oleh asas manfaat dan asas perlindungan yang kemudian disesuaikan dengan kaidah yang berlaku dimasyarakat. Masyarakat memiliki hak untuk menggunakan pelayanan kesehatan secara optimal untuk kesehatannya serta pelayanan kesehatan tradisional yang ada perlu adanya pengawasan dari pemerintah agar perlindungan hukum dapat tercapai. Ini sesuai dengan perkembangan pembangunan kesehatan. dimana saat ini telah terjadi perubahan orientasi, baik tata nilai maupun pemikiran mengenai upaya pemecahan masalah kesehatan yang dipengaruhi berbagai aspek kehidupan yang menyebabkan masyarakat yang berkemampuan secara ekonomi dan sosial akan lebih memilih pelayanan kesehatan secara alternatif atau tradisional yang sudah terjamin keamanan dan manfaatnya. Sementara itu bagi masyarakat yang tidak atau kurang berkemampuan memilih pelayanan kesehatan yang terjamin, mereka akan lebih memilih pelayanan untuk kesehatan mereka dengan biaya yang terjangkau. Dengan adanya pasal ini, jelas bahwa perlindungan hukum terhadap pasien telah dijamin oleh pemerintah.

Secara normatif, telah diterbitkan pengaturan mengenai penyelenggaraan pelayanan pengobatan tradisional yakni dalam Kepmenkes No. 1076 Tahun 2003 Tentang Penyelenggaraan Pengobatan Tradisional. Penertiban ijin pengadaan penyelenggaraan pelayanan kesehatan tradsional. Secara admisnistratif ini merupakan bentuk perlindungan terhadap para pengguna dari suatu pusat pelayanan kesehatan tradisional.

Pasal 1 Kepmenkes No.1076 Tahun 2003 memuat tentang pengertian dari masing-masing unsur pelayanan kesehatan tradisional yang mencakup pengertian dari Pengobatan tradisional adalah pengobatan dan/atau perawatan dengan cara, obat dan pengobatnya yang mengacu kepada pengalaman, ketrampilan turun temurun, dan/atau pendidikan/pelatihan, dan diterapkan sesuai dengan norma yang berlaku dalam masyarakat. Obat tradisional adalah bahan atau ramuan bahan yang berupa bahan tumbuhan, bahan hewan, bahan mineral, sediaan sarian (galenik) atau campuran bahan tersebut yang secara turun temurun telah digunakan untuk pengobatan berdasarkan pengalaman, Pengobat tradisional adalah orang yang melakukan pengobatan tradisional (alternatif), Pengobat tradisional asing adalah pengobat tradisional Warga Negara Asing yang memiliki visa tinggal terbatas atau izin tinggal terbatas atau izin tinggal tetap untuk maksud bekerja di Wilayah Republik Indonesia, Surat Terdaftar Pengobat Tradisional yang selanjutnya disebut STPT adalah bukti tertulis yang diberikan kepada pengobat tradisional yang telah melaksanakan pendaftaran, Surat Izin Pengobat Tradisional (SIPT) adalah bukti tertulis yang diberikan kepada pengobat tradisional yang metodenya telah dikaji, diteliti dan diuji terbukti aman dan bermanfaat bagi kesehatan. serta Toko Obat Tradisional adalah tempat menyimpan, melayani dan menjual obat tradisional. Disini penulis berpendapat, pasal ini didasarkan oleh asas manfaat dan asas perlindungan yang kemudian disesuaikan dengan kaidah yang berlaku dimasyarakat. Tidak semua jenis pengobatan / perawatan yang dilakukan berdasarkan pengalaman dan ketrampilan masuk dalam katagori yang dimaksudkan oleh Undang-Undang , melainkan harus memenuhi uji empirik dan tidak melanggar norma yang berlaku di masyarakat. Termasuk penggunaan obat/ ramuan didalam pelayanan kesehatan tradisional, obat/ ramuan tersebut sebelumnya harus memenuhi standarisasi dan telah melewati uji empirik dari lembaga pemerintah yang berwenang. Pengobat tradisional asing haruslah memiliki izin tinggal untuk bekerja di wilayah Indonesia. Dengan izin inilah berarti suatu pusat pelayanan kesehatan tradisional telah diteliti dan terbukti aman untuk masyarakat sehingga aspek perlindungan hukum terhadap pasiennya dapat tercapai. Pada praktiknya, banyak pusat pelayanan kesehatan tradisional di Indonesia yang tidak memiliki SIPT. Mereka hanya memiliki status terdaftar di Dinas Kesehatan setempat tanpa meningkatkan status pusat pelayanan kesehatannya menjadi berizin. Pusat pelayanan kesehatan tradisional di Indonesia harusnya memiliki status berizin agar perlindungan hukum terhadap pengguna pusat pelayanan tersebut terjamin. Dengan adanya pasal ini jelas pemerintah menjamin adanya suatu perlindungan hukum terhadap pasien. 
Pasal 2 Kepmenkes No.1076 Tahun 2003 membahas tentang Pengaturan penyelenggaraan pengobatan tradisional bertujuan untuk : membina upaya pengobatan tradisional, memberikan perlindungan kepada masyarakat, menginventarisasi jumlah pengobat tradisional, jenis dan cara pengobatannya. Disini penulis berpendapat, pasal ini mengandung asas perlindungan yang akhirnya dapat melindungi seluruh masyarakat dan terciptanya kehidupan tertib serta aman. Untuk mencapai suatu pelayanan kesehatan yang baik perlunya dukungan dari pemerintah dalam membina serta menginventarisasi pengobatan tradisional sehingga tujuan akhir dari penyelenggaraan pelayanan dapat tercapai. Saat ini tujuan dari pelayanan kesehatan tradisional ini belum tercapai. Masih banyak pengobat tradisional yang belum terinventarisasi oleh pemerintah keberadaannya. Pada praktiknya, saat ini di Dinas Kesehatan, banyak dari tempat-tempat pelayanan kesehatan tradisional yang tidak pernah melaporkan perkembangan pelayanan mereka ke pemerintah. Akan tetapi melalui pasal ini pemerintah telah menjamin adanya suatu perlindungan hukum terhadap pasien.

Pasal 3 Kepmenkes No.1076 Tahun 2003 memuat tentang klasifikasi dari pelayanan pengobatan tradisional. Penulis berpendapat pasal ini mengandung asas perlindungan terhadap pasien, sebab dengan adanya klasifikasi pengobatan tradisional yang jelas seperti ini berarti pemerintah telah melakukan perannya dalam mendukung pelayanan kesehatan tradisional. Untuk mencapai adanya suatu perlindungan hukum dibutuhkan adanya peran pemerintah didalamnya. Karena pemerintah yang memberi jaminan adanya suatu perlindungan hukum di Negara Indonesia. Pada praktiknya, saat ini banyak bermunculan jenis pengobatan tradisional di Indonesia. Baik itu pengobatan tradisional asli Indonesia maupun yang berasal dari asing. Banyak bermunculannya pengobatan tradisional dengan bermacam metode dapat menjadi penyebab sulitnya melakukan standarisasi pengobatan tradisional yang seharusnya. Akan tetapi dengan pasal ini jelas bahwa sebenarnya aspek perlindungan hukum terhadap pasien telah dijamin oleh pemerintah.

Pasal 4 Kepmenkes No.1076 Tahun 2003 bahwa Semua pengobat tradisional yang menjalankan pekerjaan pengobatan tradisional wajib mendaftarkan diri kepada Kepala Dinas Kesehatan Kabupaten/Kota setempat untuk memperoleh Surat Terdaftar Pengobat Tradisional (STPT). Pengobat tradisional dengan cara supranatural harus mendapat rekomendasi terlebih dahulu dari Kejaksaan Kabupaten/Kota setempat. Pengobat tradisional dengan cara pendekatan agama harus mendapat rekomendasi terlebih dahulu dari Kantor Departemen Agama Kabupaten/Kota setempat. Penulis berpendapat, pasal ini memuat adanya suatu asas perlindungan yang diberikan pemerintah kepada pelayanan kesehatan tradisional. Untuk menjalankan praktik pelayanan, pusat pelayanan kesehatan tradisional wajib mendapat izin dari pemerintah yakni lembaga yang berwenang. Pada praktiknya masih banyak tempat pelayanan pengobatan tradisional yang tidak terdaftar atau mendapat rekomendasi dari institusi atau lembaga yang seharusnya mewadahinya. Perlindungan hukum sendiri diberikan oleh pemerintah kepada pusat-pusat pelayanan kesehatan untuk melindungi para pengguna layanan kesehatan tersebut. Dengan pasal ini aspek perlindungan hukum terhadap pasien sebenarnya telah dijamin oleh pemerintah.

Pasal 5,6,7,8 Kepmenkes No.1076 Tahun 2003 meyebutkan tentang Tata cara memperoleh STPT yang seharusnya ini dipatuhi dan dilaksananya sesuai aturan oleh setiap pemilik atau pelaksana dari tempat pelayanan pengobatan tradisional. Penulis berpendapat pasal ini memuat adanya asas perlindungan hukum dengan adanya campur tangan dari pemerintah. Dimana untuk pendapatkan STPT pusat pelayanan kesehatan tradisional wajib mentaati tata cara memperoleh STPT yaitu: Pengobat tradisional harus mengajukan permohonan dengan disertai kelengkapan pendaftaran kepada Kepala Dinas Kesehatan Kabupaten/ Kota dimana pengobat tradisional berada. 
Kelengkapan pendaftaran sebagaimana dimaksud meliputi :

1) Biodata pengobat tradisional sebagaimana contoh Formulir B.

2) Fotokopi KTP.

3) Surat keterangan Kepala Desa / Lurah tempat melakukan pekerjaan sebagai pengobat tradisional.

4) Rekomendasi dari asosiasi/organisasi profesi di bidang pengobatan tradisional yang bersangkutan.

5) Fotokopi sertifikat / ijazah pengobatan tradisional yang dimiliki.

6) Surat pengantar Puskesmas setempat.

7) Pas foto ukuran $4 \times 6 \mathrm{~cm}$ sebanyak 2(dua) lembar.

8) Rekomendasi Kejaksaan Kabupaten/Kota bagi pengobat tradisional klasifikasi supranatural dan Kantor Departemen Agama Kabupaten/ Kota bagi pengobat tradisional klasifikasi pendekatan agama.

STPT yang sudah diterbitkan ini berlaku untuk 1 tahun hanya di tempat STPT diterbitkan. Setiap pusat pelayanan kesehatan juga harus melakukan pelaporan secara berkala agar pemerintah dapat melakukan pengawasan terhadap pelayanan kesehatan tradisional yang ada. Pada praktiknya masih banyak pusat pelayanan kesehatan tradisional yang tidak mematuhi tata cara ini dan juga tidak melakukan pelaporan kepada dinas terkait. Akan tetapi dengan pasal ini dapat dilihat bahwa pemerintah telah menjamin adanya suatu perlindungan hukum terhadap pasien.

Pasal 9,10 dan 11 Kepmenkes No.1076 Tahun 2003 meyebutkan tentang perijinan dan tata cara memperoleh ijin dalam melakukan suatu pelayanan kesehatan tradisional dimana nantinya pengobat tradisional yang metodenya telah memenuhi persyaratan penapisan, pengkajian, penelitian dan pengujian serta terbukti aman dan bermanfaat bagi kesehatan dan memberikan suatu perlindungan bagi pengguna suatu pelayanan kesehatan tradisional. Penulis berpendapat bahwa pasal ini memuat tentang asas perlindungan. Pusat pelayanan kesehatan tradisional yang ingin memperoleh izin resmi wajib melakukan kelengkapan perizinan sesuai tata cara yang ditetapkan, yaitu: Pengobat tradisional mengajukan permohonan SIPT kepada Kepala Dinas Kesehatan Kabupaten/Kota. Kelengkapan permohonan meliputi :

1) Biodata pengobat tradisional sebagaimana contoh Formulir B.

2) Fotokopi KTP.

3) Surat keterangan Kepala Desa / Lurah tempat melakukan pekerjaan sebagai pengobat tradisional.

4) Peta lokasi usaha dan denah ruangan.

5) Rekomendasi dari asosiasi/organisasi profesi di bidang pengobatan tradisional yang bersangkutan.

6) Fotokopi sertifikat / ijazah pengobatan tradisional.

7) Surat pengantar Puskesmas setempat

8) Pas foto ukuran $4 \times 6 \mathrm{~cm}$ sebanyak 2(dua ) lembar.

Banyak dari tempat pelayanan kesehatan ini yang hanya dalam status terdaftar di dinas kesehatan tanpa ada lanjutan menjadi tempat pelayanan yang berizin. Akan tetapi dengan pasal ini pemerintah telah menjamin adanya suatu perlindungan hukum terhadap pasien. 
Pasal 12 dan 13 Kepmenkes No.1076 Tahun 2003 menyebutkan tentang bagaimana penyelenggaraan pelayanan pengobatan tradisional diantaranya bahwa suatu pengobatan tradisional harus memberikan upaya peningkatan kesehatan, pencegahan penyakit, penyembuhan penyakit, dan/atau pemulihan kesehatan yang hanya dapat dilakukan apabila :

a. tidak membahayakan jiwa atau melanggar susila dan kaidah agama serta kepercayaan terhadap Tuhan Yang Maha Esa yang diakui di Indonesia.

b. aman dan bermanfaat bagi kesehatan;

c. tidak bertentangan dengan upaya peningkatan derajat kesehatan masyarakat;

d. tidak bertentangan dengan norma dan nilai yang hidup dalam masyarakat; agar dapat tercapainya suatu perlindungan bagi penggunanya.

Penulis berpendapat, pasal ini memuat asas manfaat dimana penyelengaraan pelayanan kesehatan harus bisa memberi manfaat bagi masyarakat. Pasal ini juga memuat adanya asas perlindungan dimana penyelenggaraan pelayanan kesehatan tradisional harus dapat melindungi segenap hak masyarakat serta tidak membahayakan jiwa masyarakat pengguna layanan kesehatan, yang kemudian disesuaikan dengan kaidah agama dan susila yang berlaku di masyarakat. Ketentuan ini apabila ditaati dapat memberikan perlindungan hukum terhadap pasien. Apabila terjadi pelanggaran, akan dikenakan sanksi sesuai undang-undang kesehatan.

Pasal 14 Kepmenkes No.1076 Tahun 2003 berbicara tentang kewajiban sarana prasarana dari suatu tempat pengobatan tradisional, yaitu: Pengobat tradisional yang melakukan pekerjaan/praktik sebagai pengobat tradisional harus memiliki STPT atau SIPT. Pengobat tradisional juga berkewajiban menyediakan :

a. Ruang kerja dengan ukuran minimal $2 \times 2,50 \mathrm{~m} 2$.

b. Ruang tunggu.

c. Papan nama pengobat tradisional dengan mencantumkan surat terdaftar/ surat ijin pengobat tradisional, serta luas maksimal papan 1 x 1,5 m2.

d. Kamar kecil yang terpisah dari ruang pengobatan.

e. Penerangan yang baik sehingga dapat membedakan warna dengan jelas.

f. Sarana dan prasarana yang memenuhi persyaratan hygiene dan sanitasi.

g. Ramuan/obat tradisional yang memenuhi persyaratan.

h. Pencatatan sesuai kebutuhan.

Penulis berpendapat pada pasal ini mengandung asas perlindungan hukum, dimana pengobat tradisional diwajibkan memiliki STPT dan SIPT. Ini menujukkan bahwa pemerintah memegang andil dalam melindungi para pelaksana dan pengguna pelayanan kesehatan tradisional. Pusat pelayanan kesehatan tradisional juga diwajibkan memiliki sarana dan prasarana pendukung pelayanan. Pada praktiknya ada beberapa dari tempat pelayanan kesehatan tradisional yang tidak memenuhi kewajiban yang seharusnya. Banyaknya pengobat tradisional yang hanya memiliki STPT ataupun sama sekali tidak memiliki STPT ataupun SIPT. Serta masih terdapatnya tempat-tempat pelayanan pengobatan tradisional yang kurang memenuhi standar hygiene dari suatu pusat pelayanan kesehatan dengan sarana prasarana yang sangat minim. Melalui ketentuan ini pemerintah telah menjamin adanya suatu perlindungan hukum terhadap pasien. Apabila terjadi kesalahan atau ketidakpatuhan terhadap peraturan ini, pelaksana pelayanan kesehatan tradisional akan dikenakan sanksi sesuai undang undang kesehatan.

Pasal 15 Kepmenkes No.1076 Tahun 2003 bahwa Pengobat tradisional harus memberikan informasi yang jelas dan tepat kepada pasien tentang tindakan pengobatan yang dilakukannya. Informasi diberikan secara lisan yang mencakup keuntungan dan kerugian dari tindakan pengobatan yang dilakukan. Semua tindakan pengobatan tradisional yang akan dilakukan terhadap pasien harus mendapat persetujuan pasien dan/atau keluarganya. Persetujuan dapat 
diberikan secara tertulis maupun lisan. Setiap tindakan pengobatan tradisional yang mengandung risiko tinggi bagi pasien harus dengan persetujuan tertulis yang ditandatangani oleh yang berhak memberikan persetujuan. Penulis berpendapat bahwa pasal ini mengandung asas perlindungan hukum dimana pasien akan dilindungi melalui informasi yang diberikan dan dengan persetujuan yang jelas. Informasi yang jelas akan menjadi bukti bahwa pusat pelayanan kesehatan tersebut telah melaksanakan fungsinya dengan baik. Pasien juga memiliki hak untuk mendapatkan informasi yang jelas mengenai kesehatan atau tindakan yang akan dilakukan kepada dirinya sesuai dengan pasal 4 Undang-undang no.36 Tahun 2009 Tentang kesehatan. serta melakukan persetujuan atas tindakan yang dilakukan terhadap dirinya agar aspek perlindungan hukum dapat tercapai. Akan tetapi hanya beberapa dari tempat pelayanan kesehatan yang memberikan informasi secara jelas baik lisan maupun tulisan. Pemberian informasi dan persetujuan antara pasien dan praktisi pelayanan kesehatan tradisional lebih kepada persetujuan lisan yang tidak langsung. Melalui pasal ini jelas aspek perlindungan hukum terhadap pasien terjamin oleh pemerintah.

Pasal 16 Kepmenkes No.1076 Tahun 2003 menyebutkan bahwa Pengobat tradisional hanya dapat menggunakan peralatan yang aman bagi kesehatan dan sesuai dengan metode/keilmuannya. Pengobat tradisional dilarang menggunakan peralatan kedokteran dan penunjang diagnostik kedokteran. Pasal ini mengandung asas perlindungan terhadap pasien dimana peralatan yang digunakan pada pelayanan kesehatan tradisional ini wajib menggunakan peralatan yang aman. Saat ini banyak pengobatan tradisional yang muncul dengan metode dan cara supranatural yang menggunakan peralatan penunjang terapi seperti kayu, paku yang peralatan ini tidak bisa dijamin keamanannya serta metode yang digunakannya juga tidak sesuai dengan syarat dari suatu pelayanan kesehatan tradisional harus masuk akal tidak bisa terpenuhi. Akan tetapi dari segi aturan yang ada, jelas perlindungan hukum terhadap pasiennya terjamin.

Pasal 17 dan 18 Kepmenkes No.1076 Tahun 2003 berbicara tentang obat tradisional. Penulis berpendapat pasal ini mengandung asas perlindungan hukum terhadap pasien. Dimana seharusnya Penggunaan obat tradisional harus memenuhi standar dan/atau persyaratan sesuai dengan ketentuan peraturan perundang-undangan yang berlaku. Dan setiap obat atau ramuan yang digunakan pada pelayanan kesehatan tradisional haruslah melewati uji standarisasi terlebih dahulu di lembaga pemerintahan berwenang. Dengan adanya peraturan ini jelas bahwa perlindungan pasien sudah terjamin dari pemerintah. Apabila terjadi pelanggaran maka akan dikenakan sanksi sesuai undang-undang perlindungan konsumen. Dimana secara professionalisme dan penyediaan obat, pelayanan kesehatan tradisional juga diatur dengan undang-undang perlindungan konsumen.

Pasal 19 Kepmenkes No.1076 Tahun 2003 menyebutkan bahwa Pengobat tradisional dalam memberikan pelayanan wajib membuat catatan status pasien. Penulis berpendapat, pasal ini memuat adanya asas perlindungan hukum melalui kewajiban pengobat tradisional untuk membuat catetan status pasien. Sebab pasien memiliki hak untuk mendapatkan keterangan tentang kesehatannya jika dibutuhkan. Dengan pasal ini juga pemerintah telah menjamin adannya suatu perlindungan hukum terhadap pasien.

Pasal 20 Kepmenkes No.1076 Tahun 2003 menyebutkan bahwa pengobat tradisional dilarang memberikan dan/atau menggunakan obat modern, obat keras, narkotika dan psikotropika serta bahan berbahaya. Serta Pengobat tradisional dilarang menggunakan obat tradisional yang diproduksi oleh industri obat tradisional (pabrikan) yang tidak terdaftar dan obat tradisional racikan yang bahan bakunya tidak memenuhi persyaratan kesehatan. Pasal ini memuat adanya asas perlindungan terhadap pasien. Akan tetapi saat ini hanya sedikit dari pengobat tradisional yang tidak mematuhi hal ini. Ada beberapa pengobat tradisional yang mencampurkan ramuan mereka dengan obat-obatan modern kedalam ramuan tradisional mereka demi mendapatkan efek obat yang cepat untuk kesehatan pasien mereka. Masih ada juga beberapa pengobat tradisional yang menggunakan obat/ramuan dari pabrik yang tidak terdaftar dengan 
alasan obat-obat yang dproduksi pabrik ini lebih murah dan menguntungkan bagi pengobat tradisional tanpa memperhatikan aspek perlindungan terhadap si pasien. Untuk itu apabila terjadi pelanggaran terhadap pasal ini, dapat dikenakan sanksi sesuai undang-undang kesehatan.

Pasal 21 Kepmenkes No.1076 Tahun 2003 bahwa Pengobat tradisional wajib melaporkan kegiatannya tiap 4 (empat) bulan sekali kepada Kepala Dinas Kesehatan Kabupaten/Kota. Laporan meliputi jumlah dan jenis kelamin pasien, jenis penyakit, metode dan cara pengobatannya. Penulis berpendapat bahwa pasal ini memuat asas perlindungan hukum. Dimana adanya peran pemerintah selaku pemberi perlindungan hukum dalam melakukan pengawasan pada tempat pelayanan kesehatan dan adanya suatu kerjasama yang baik antara pemerintah dan pelaku pengobat tradisional. Suatu tempat pelayanan kesehatan tidak dapat berdiri sendiri tanpa pengawasan, bimbingan dari pemerintah. Harus ada pengawasan dan bimbingan lembaga yang berwenang atau pemerintah agar tercapai suatu perlindungan bagi pasiennya. Pada pasal ini terlihat bahwa aspek perlindungan hukum terhadap pasien telah dijamin oleh pemerintah.

Pasal 22 Kepmenkes No.1076 Tahun 2003 bahwa Pengobat tradisional yang tidak mampu mengobati pasiennya atau pasien dalam keadaan gawat darurat, harus merujuk pasiennya ke sarana pelayanan kesehatan terdekat. Penulis berpendapat bahwa pada pasal ini terdapat asas perlindungan terhadap pasien. Dimana keselamatan pasien menjadi faktor utama didalam pelayanan kesehatan, dan pemerintah telah menjamin adanya suatu perlindungan hukum terhadap pasien. Tetapi pada kenyataannya ada pasien-pasien yang meninggal ditangan para pengobat tradisional. Dimana kurangnya kesadaran dari praktisi pengobat tradisional untuk merujuk dan kondisi ekonomi pasien juga yang terkadang yang membuat pasien tidak mau dirujuk ke pusat kesehatan terdekat seperti rumah sakit. Apabila terjadi kesalahan tersebut pengobat tradisional akan dikenakan sanksi sesuai aturan undang-undang kesehatan.

Pasal 23 Kepmenkes No.1076 Tahun 2003 bahwa pengobat tradisional dilarang mempromosikan diri secara berlebihan dan memberikan informasi yang menyesatkan. Informasi menyesatkan antara lain meliputi :

a. penggunaan gelar-gelar tanpa melalui jenjang pendidikan dari sarana pendidikan yang terakreditasi;

b. menginformasikan bahwa pengobatan tersebut dapat menyembuhkan semua penyakit;

c. menginformasikan telah memiliki surat terdaftar/surat izin sebagai pengobat tradisional yang pada kenyataannya tidak dimilikinya.

Penulis berpendapat bahwa pasal ini memuat asas perlindungan terhadap pasien. Akan tetapi saat ini dengan makin terbukanya kesempatan promosi kesehatan, banyak tempat-tempat pelayanan kesehatan yang berlomba-lomba melakukakan promosi mau itu lewat iklan maupun televisi secara berlebihan dan menggunakan informasi yang menyesatkan dengan memberi jaminan kesembuhan pasien 100 persen. Melalui peraturan ini pemerintah telah menjamin adanya suatu perlindungan hukum terhadap pasien.

Pasal 24 Kepmenkes No.1076 Tahun 2003 menyebutkan bahwa suatu pelayanan kesehatan tradisional perlu dibina dan diawasi oleh pemerintah agar dapat dipertanggungjawabkan manfaat dan keamanannya. Disini penulis berpendapat bahwa pasal ini memuat adanya asas perlindungan terhadap pasien. Akan tetapi masih banyak pelayanan pengobatan tradisional yang lolos dari pengawasan pemerintah. Dikarenakan banyak dari tempat pelayanan kesehatan tradisional yang tidak mendaftarkan tempat pelayanan mereka dan tidak melaporkan usaha mereka ke lembaga yang seharusnya. Melalui pasal ini pemerintah menjamin adanya perlindungan melalui pengawasan dan pembinaan yang akan dilakukan 
Pasal 25 dan 26 Kepmenkes No.1076 Tahun 2003 menyebutkan tentang standar dari suatu toko obat tradisional. Penulis berpendapat bahwa pasal ini memuat asas perlindungan terhadap pasien. Setiap toko obat tradisional harus mematuhi standar obat dan toko obat seharusnya, dan bertanggung jawab terhadap keamanan, mutu, dan keabsahan obat tradisional yang dikelola sehingga aspek perlindungan hukum yang diharapkan dapat terjamin. Saat ini banyak toko obat tradisional yang hampir memenuhi standar dan kewajiban dari suatu tempat pelayanan tradisional. Melalui undang undang ini juga pemerintah telah menjamin adanya suatu perlindungan hukum terhadap pasien sebagai pengguna pelayanan kesehatan ini. Apabila terjadi pelanggaran terhadap peraturan ini, akan dikenakan sanksi sesuai aturan undang-undang kesehatan.

Pasal 27 sampai 29 Kepmenkes No.1076 Tahun 2003 menyebutkan tentang pengobat tradisional luar Indonesia, baik itu pengobatan tradisional yang berasal dari asing ataupun pengobat tradisional Indonesia yang belajar di luar. Penulis berpendapat pasal ini memuat adanya asas perlindungan terhadap pasien. Saat ini makin banyak bermunculan pusat-pusat pelayanan kesehatan tradisional asing dengan berbagai metode kesembuhan. Akan tetapi pada praktiknya pelayanan kesehatan tradisional asing ini tidak jauh berbeda dengan pengobat tradisonal asli Indonesia yang belum memenuhi standar suatu pelayanan kesehatan. akan tetapi melalui undang-undang ini perintah menjamin adanya suatu perlindungan hukum terhadap pasien.

Pasal 30 Kepmenkes No.1076 Tahun 2003 menyatakan bahwa Setiap pengobat tradisional harus mengikuti pendidikan, pelatihan atau kursus untuk peningkatan pengetahuan dan ketrampilan keilmuan. Pelatihan atau kursus pengobat tradisional sebagaimana yang dimaksud diselenggarakan oleh Dinas Kesehatan, Puskesmas, Organisasi Profesi di bidang kesehatan, asosiasi/organisasi profesi di bidang pengobatan tradisional dan/atau intansi yang berwenang. Sentra P3T dan/atau instansi/institusi yang berwenang berperan mengembangkan model/bentuk intervensi, pendidikan dan pelatihan sebelum diterapkan secara luas di masyarakat. Penulis berpendapat, pasal ini memuat adanya asas perlindungan terhadap pasien. Dimana pengobat tradisional diwajibkan untuk meningkatkan pengetahuan dan keterampilannya melalui pendidikan atau kursus yang sesuai bidang keahliannya untuk meningkatkan standar pengetahuan dirinya sehingga dapat memberikan pelayanan kesehatan yang sesuai standar terbaru yang ada agar dapat mencapai kesehatan pasien yang optimal. Pada praktiknya, hanya beberapa dari pengobat tradisional yang terus menambah pengetahuannya melalui kursus atau pelatihan yang ada. Hal ini akan membuktikan seberapa besar sumber daya masyarakat ( SDM ) pengobat tradisional itu sendiri. Melalui pasal ini pemerintah telah menunjukkan perannya dalam memberi perlindungan hukum terhadap pasien.

Pasal 31 sampai 34 Kepmenkes No.1076 Tahun 2003 menyebutkan tentang pembinaan dan pengawasan pemerintah ataupun dinas terkait terhadap pusat pelayanan kesehatan tradisional. Disini penulis berpendapat bahwa pasal ini memuat asas perlindungan terhadap pasien, dimana pelayanan kesehatan yang baik harusnya berada dalam pengawasan dan pembinaan dari pemerintah. Melalui aturan undang undang ini pemerintah sebagai pemberi perlindungan hukum terhadap masyarakatnya menjamin adanya pengawasan dan pembinaan tersebut sehingga aspek perlindungan pasien akan terjamin

Dalam hal tanggungjawab hukum, pusat pelayanan kesehatan dikelola oleh suatu badan atau perseorangan dengan mengacu pada keuntungan (profit oriented), dapat saja dianggap sebagai pelaku usaha dan pasien dianggap sebagai konsumen kesehatan. Sehingga dalam hal ini, perlindungan bagi pasien, dapat dilihat dari sisi perlindungan konsumen sebagaimana diatur dalam Undang-Undang Nomor 8 Tahun 1999 Tentang Perlindungan Konsumen. Tanggung jawab hukum pelaku usaha hanya berorientasi pada produk dan tanggung jawabnya hanya dibatasi terhadap sisi pelayanan kesehatan. 
Setelah dilakukan analisis kualitattif di atas, antara tinjauan dari pelayanan kesehatan tradisional dengan tinjauan mengenai perlindungan hukum terhadap pasien, dapat dirumuskan jawaban sementara yakni: jika masih banyaknya pelayanan kesehatan tradisional yang belum memenuhi standar dan syarat dari suatu pelayanan kesehatan sehingga suatu perlindungan terhadap pasien belum tercapai optimal. Pemerintah seyogyanya dapat melakukan pengawasan di setiap pelaksanaan pelayanan kesehatan tradisional agar tercapai suatu pelindungan yang optimal juga.

\section{Saran}

Berdasarkan hasil penelitian, penulis memberi saran sebagai berikut:

1. Pelayanan kesehatan tradisional yang diberikan harus memenuhi hukum dan menghindari terjadinya kelalaian oleh praktisinya.

2. Pasien dari pengobatan tradisonal harus memahami hak dan kewajibannya sebagai konsumen jasa medis.

3. Pemerintah harus melakukan pengawasan dan bimbingan terhadap setiap pelayanan kesehatan tradisional yang ada demi tercapai suatu perlindungan hukum.

4. Perlu adanya suatu kesepakatan standar pelayanan kesehatan tradisional baik itu pelayanan kesehatan dengan keterampilan maupun ramuan yang terstandarisasi dan sosialisasi nya jelas serta dilakukan berkala oleh dinas terkait.

5. Sosialisasi peraturan dan perundangan mengenai pelayanan kesehatan tradisional harus digalakkan.

\section{DAFTAR PUSTAKA}

\section{Sumber buku}

Clinical Practice Guideline, 1990

Jusuf Hanafiah, Amri Amir, 2007. Etika Kedokteran dan Hukum Kesehatan, Edisi 4, Jakarta: EGC, hlm.142

Koermiatmanto Soetoprawiro, Peraturan Perindungan Hak-Hak Perempuan dan Anak-Anak dalam Hukum Kewarganegaraan Indonesia, Journal Hukum Pro Justisia XX nomor 3 Juli,Bandung, 2002, hlm.20.

\section{Sumber undang-undang}

Undang undang Nomor 8 tahun 1999 Tentang Perlindungan Konsumen

Undang undang Nomor 36 Tahun 2009 Tentang Kesehatan

Peraturan Menteri Kesehatan RI Nomor 1186 Tahun 1996 Tentang Pemanfaatan Akupunktur di Sarana Pelayanan Kesehatan

Keputusan Menteri Kesehatan Nomor 1076 Tahun 2003 Tentang Penyelenggaraan pengobatan Tradisional

Peraturan Menteri Kesehatan RI Nomor 1109 Tahun 2007 Tentang Penyelenggaraan Pengobatan Komplementer- Alternatif di Fasilitas Pelayanan Kesehatan 